Wilkins, Wilbur, Squire, Ryan, and some others, are very commonly taught, even in Female Boarding Schools, is very well known; but prior to the apo pearance of Gummere's Astronomy there was no work known in this country, and indeed we may say, of moderate size, in the English language, well adapted to initiate the student in the theoretical doctrines of this most elevated science, and to confirm his knowledge and his taste by placing before him the means, and making it a part of his duty, to go over the demonstrations, to enter the calculations, and to form projections of some of the more interesting phenomena. Without this, it is impossible fully to comprehend and justly to appreciate the labours of those great minds from whose discoveries the world is deriving such a vast accession of intellectual power. Popular illustrations are better than nothing. They may serve to awaken curiosity, and possibly stimulate a few to further investigation and deeper study; but every teacher who is imbued with a real love of mathematics, must have felt, like the estimable author of this work, the superficiality of all the common school books, and the necessity of a treatise which should better answer the designs of thorough instruction. Gummere's treatise is adopted in some of the colleges, and is now, we are pleased to learn, a text book in the highest mathematical school in this country, the military academy at West Point. This second edition, the author informs us, "has received considerable additions in both parts. A general analytical investigation of eclipses of the sun, occultations, and transits has been introduced, and the formulæ obtained are applied in practical problems for calculating these phenomena. The table of the sun's epochs, commencing with the year 1836, has been improved by the application of Bessel's corrections. The Tables of Epochs both for the Sun and Moon have been extended, and tables for the planet Mercury abridged from Lindenau's tables and adapted to the meridian of Greenwich, have been introduced, serving to illustrate the method of calculating the place of a planet; and they are sufficiently accurate for determining nearly the times of a transit of this planet over the Sun's disc. Several other useful tables have been added.

Whoever wishes to teach the elements of practical Astronomy without the trouble and expense of importing books of tables, will find this work almost indispensable. It must have cost the author much time and labour, and an ingenious analytical method of his own, for calculating eclipses, is not elsewhere to be met with, except perhaps a paper in the transactions of the American Philosophical Society, furnished by himself.

\title{
Mechanies' Register.
}

Specification of a patent granted to $\mathbf{U}_{\mathrm{RI}}$ Emmons, of Freehold, Monmouth County, New Jersey, for a single Rail, Rail-Road.

To all whom it may concern: be it known, that I, Uri Emmons, of Freehold, in the county of Monmouth, and State of New Jersey, have invented certain improvements in the manner of constructing rail-roads of that kind, in which the carriage way consists of a single rail, elevated upon posts; and I do hereby declare that the following is a full and exact description thereof.

The general construction of the single rail which I use is the same with that for which letters patent were obtained by a certain Henry R. Palmer, in England, in the year 1821. This single rail is elevated upon posts 
set in the ground, the rail being secured on the tops of the posts, and covered with an iron plate on its upper side. The strength of the rail must be such as to sustain the load which is to bear upon it, and this will be governed by the distance of the posts apart which support it. The accompanying perspective drawing represents the rail, supported upon posts and covered by the iron rail plate. 'The posts may sometimes be mortised into a ground sill, but as ground is generally uneven, and as this mode of constructing rail roads is intended to obviate the necessity, in the greater number of cases, of excavating and embanking, by giving the posts the proper length to reach the level of the rail, a horizontal ground sill can rarely be used; and it is desirable to be able to fix these posts firmly at their lower ends, by means which shall be adapted to uncven ground, be efficient without being costly, and be well calculated to keep the posts in a vertical position, and allow of their adjustment when necessary. To effect this I take truaks

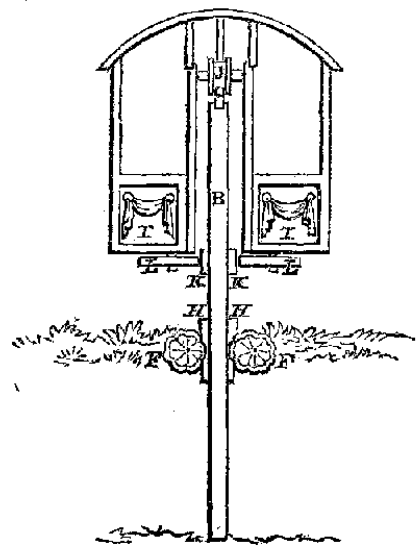

of trees, from which $I$ hew off a portion of one side, so that they will lie along against the posts, as shown in the transverse view at F. These logs may be buried partially, or wholly, in the ground, and they must be bound together by bolts, or cross-ties, in any convenient way. Between the vertical posts and the above named logs $I$ insert wedges $H$, $\mathbf{H}$, by the driving of which the posts may be, at any time, firmly fixed in a vertical position, and regulated as may be desired. When the vertical posts are of considerable length, lateral braces must be used, and these may rise from cross sills which rest upon the trees, or logs, and which may serve at the same time as cross ties to these logs.

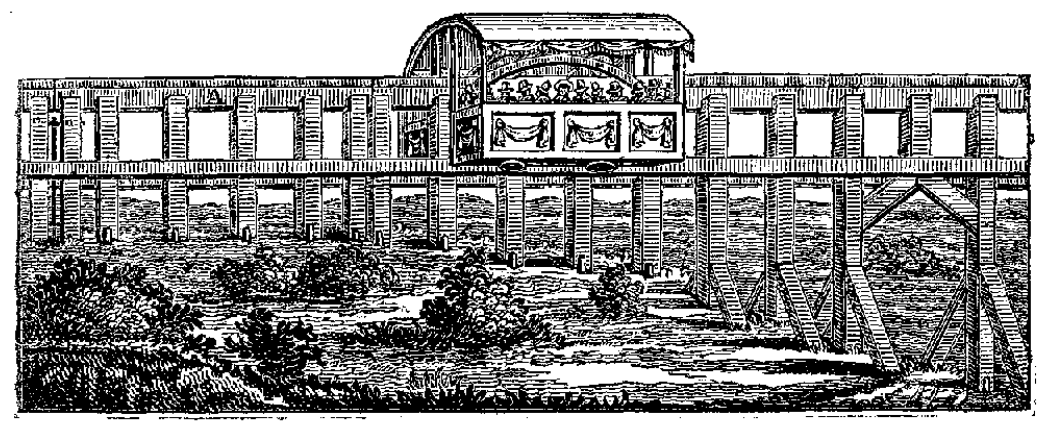

Where it has been proposed to use a single rail, such as I have described, it has also been intended to construct a car, or carriage consisting of two parts, to be suspended from the rail, one part on each side thereof, with wheels between them, near their tops, to bear upon the rail, in a manner snalogous to that shown in the transverse view, where $I, I$, are the two parts of the car, or carriage, and $J$, one of the running wheels. The main improvement which I have made in this part consists in the employment of guide rails $\mathbf{K} \mathrm{K}$, which run along on each side of the posts, to which they are firmly affixed. These may ordinarily be placed about three feet

VoL. XIX.-No. 6.-June, 1837. 
below the top of the rail, and opposite to them; upon each section of the car, or carriage, I place friction rollers, or wheels $\mathbf{L}, \mathbf{L}$, which generally run free of the guide rails, but come into contact therewith when, from any cause, the carriage tends more towards the rail on one side than on the other. Other modes of fixing guide rails, and friction rollers, may be devised which will be substantially the same in operation as that above described; as, for example, there may be an edged rail running along under one section of the car or carriage, supported by arms from the vertical posts, and two friction rollers attached to the under side of the section of the car, or earriage, may bear, one on each side of such edge rail, or plank. Such a plan, however, would not, in my opinion, be equally good with that first described, and $I$ give it therefore, merely, as an exemplification of one variation of my plan. The turn-outs which I intend to use resemble those described by the before-named Palmer, and I do not, therefore, claim any thing new in this part of the structure. But what I do claim as of my invention is the manner herein described of fixing and regulating the vertical posts by means of logs placed in the ground, along their lower ends, with wedges to be driven in between the logs and the posts. I also claim the employment of guide rails and friction wheels in a single rail rail-road, placed in the manner, and for the purpose described, whether the same be effected precisely in the way herein set forth, or in any other analogous thereto, and procucing a like result.

URI Emmons.

\section{Preservation of Zoological Specimens.}

I have often noticed with regret, both in some public and private museums, in this country, that the damp was making fearful inroads among the zoological specimens; and, as I learned, while in France, some time since, a most simple and efficacious remedy for that evil, I beg to submit it to you for the benefit of your readers and the public.

A glazed flower-pan, of the size of a dessert plate, placed in the cases, at intervals of 8 or 10 feet, and filled with quicklime, will rapidly imbibe all damps, and will only require renewing when it is found that the lime is completely saturated.

As a preventive to moth in museums, I have seen used, and have used myself with great effect, the huile de pétrole, put into glass vessels like shallow finger-glasses; and four or five in a case of 20 feet long will produce so powerful an effluvium, that it is necessary to have as many watch-glasses, with small portions of musk in them, to make it bearable. But this, in good air-tight cases, is of little consequence.-Kent, Dover, Jan. 5, 1837.

.

Loudon's Mag. Niat. History.

\section{New Bee Hive.}

An inhabitant of Connecticut, Mr. Judd, has invented a contrivance, by means of which bees are made to build their cells, and deposit their honey in the chamber of a dwelling-house, in neat litlle drawers, from which it may be taken fresh by the owner, without killing the insect. The New York Gazelte describes it as follows:-_' The hive has the appearance of, and is in part, a mahogany bureau or sideboard, with drawers above and a closet below, with glass doors. The case or bureau is designed to be placed in a chamber of the house, or any other suitable building, and connected with the open air or outside of the house by a tube passing through the wall. 